\title{
Parks Canada/University of Waterloo Liaison Programme
}

The liaison agreement between Parks Canada and the University of Waterloo, in effect since May 1983, has led to a productive period, with extended relations between the University's Faculty of Environmental Studies, the Department of Recreation in the Faculty of Human Kinetics and Leisure Studies, and Parks Canada. Advances have been made particularly in the areas of staff exchange, a documentation centre, an Occasional Paper Series (see below), and a review and compilation of training opportunities for Parks Canada staff that is offered by the University.

The undersigned Resident Liaison Officer participated extensively in teaching activities in both the Faculty of Environmental Studies and the Faculty of Human Kinetics and Leisure Studies during the fall and winter terms of 1983. In addition, several Parks Canada staff members participated in various courses on a 'guest lecturer' basis, while many students took the opportunity of consulting with the Parks Canada Liaison Officer on matters of career development, research, thesis preparation, etc.

A documentation centre of approximately one hundred and seventy volumes of government publications was established in the liaison office situated in the Environmental Studies Building of the University of Waterloo. These publications are available for perusal on-site or during short-term loans. Two Occasional Papers, 'Canadian National Park and Heritage Area Research Needs and Funding Sources', by Robert Graham \& Wendy Parkes, and 'External Perspectives on Parks Canada Futures Strategies, 1986-2001', by Professor J. Gordon Nelson, were completed*, while two more are in preparation for imminent publication by the Committee at the University.

Progress was made in the development of a training programme for Parks Canada staff by the University through an $\mathrm{ad}$ hoc publication entitled 'University of Waterloo Courses of Interest to Parks Canada Staff, 1984-85'. In addition, an annual series of selected readings from conservation journals was initiated, for circulation to Parks Canada field personnel.

The coming year will feature a Public Lecture Series on 'Heritage Use and Conservation', presented in conjunction with a graduate course sponsored by the Parks Canada/University of Waterloo Liaison Committee, led and coordinated by Professor Nelson and the Resident Liaison Officer, while several additional 'occasional papers' will be published on pertinent topics. The same Committee will also be involved in activities commemorating the one-hundredth anniversary of the Canadian National Parks Service.

\section{E. BRUCE WILSON, Resident Liaison Officer}

Parks Canada/University of Waterloo Liaison Committee clo Faculty of Environment Studies

University of Waterloo

Waterloo

Ontario N2L $3 G 1$

Canada.

*These papers are available at $\$ \mathrm{Can} 10$ and 6.50 , respectively, including postage, at the above address.

\section{Conservationists Call for 'No Compromise' on IWC Commercial Whaling Moratorium}

Conservationists world-wide have expressed alarm at proposals by a number of International Whaling Commission member nations to establish a 'non-commercial' category of whaling. The new definition would allow a limited form of whale-hunting to continue after the IWC moratorium goes into effect progressively in 1985-86.

On the eve of the 36th Annual Meeting of the IWC, in Buenos Aires, Argentina, 18-23 June 1984, Sir Peter Scott, Chairman of the World Wildlife Fund's International Council, said:

'There is no justification for any further compromise allowing continued catching of whales from depleted stocks or stocks whose status is extremely uncertain. The moratorium was already a compromise, with a three-years' period of grace being given to whaling countries to scale down their operations and have time to find alternative employment for the communities involved.'

The proposed category of whaling would be neither 'commercial' nor 'aboriginal-subsistence' whaling, both of which are currently recognized by the IWC. Features of this new 'noncommercial' category might include prohibition of international trade in resulting whale products, requirements that the whaling boats be owner-operated, and that the owners be dependent on fishing for a major portion of their income.

The chief proponent of the new definition is Norway, which claims that its coastal communities with traditional offshore whaling would be the main beneficiaries. Other nations that would be likely to benefit from the new category would be Brazil, Japan, Iceland, and possibly Spain and Peru.
The International Union for Conservation of Nature and Natural Resources (IUCN), representing some 500 government and private organizations, and the World Wildlife Fund, have urged Japan, Norway, and the USSR, to withdraw their objections to the IWC decision for a pause in all commercial whaling, voted in by the Commission in 1982. The moratorium on commercial whaling, which is due to begin during $1986, \dagger$ is designed inter alia to allow scientists from IWC countries and other nations to continue scientific research on the dynamics of whale stocks.

According to IUCN and WWF, scientific evaluation of whale stock-assessments shows that the level of scientific uncertainty is greater than had previously been thought. Thus, the sister organizations call on all nations to make greater use of benign research (study which does not kill the animals) and urge IWC member nations to allow the world's whales to be given a chance to recover until their future can be safeguarded by improved understanding and safe methods of management.

DONALD Allan
$\quad \&$
PETER KRAMER
World Conservation Centre
Avenue du Mont-Blanc
1196 Gland, Switzerland.

$\uparrow$ The precise dates we understand will vary according to the breeding seasons of the species concerned.-Ed. 